\title{
Comparison of Agrobacterium-mediated of Five Alfalfa (Medicago sativa L.) Cultivars Using the GUS Reporter Gene
}

\author{
Sang-Hoon Lee ${ }^{1}$, Ki-Yong Kim¹, Hyung Soo Park ${ }^{1}$, Joon-Yung Cha ${ }^{2}$ and Ki-Won Lee ${ }^{1, *}$ \\ ${ }^{1}$ Grassland \& Forages Division, National Institute of Animal Science, Rural Development Administration, Cheonan, 330-801, \\ Republic of Korea, ${ }^{2}$ Division of Applied Life Science (BK21Plus), Plant Molecular Biology and Biotechnology Research \\ Center (PMBBRC), Gyeongsang National University, Jinju 660-701, Republic of Korea
}

\begin{abstract}
Alfalfa (Medicago sativa L.) is one of the most important forage legumes in the world. It has been demanded to establish the efficient transformation system in commercial varieties of alfalfa for forage molecular breeding and production of varieties possessing new characteristics. To approach this, genetic transformation techniques have been developed and modified. This work was performed to establish conditions for effective transformation of commercial alfalfa cultivars, Xinjiang Daye, ABT405, Vernal, Wintergreen and Alfagraze. GUS gene was used as a transgene and cotyledon and hypocotyl as a source of explants. Transformation efficiencies differed from 0 to $7.9 \%$ among alfalfa cultivars. Highest transformation efficiencies were observed in the cultivar Xinjiang Daye. The integration and expression of the transgenes in the transformed alfalfa plants was confirmed by polymerase chain reaction(PCR) and histochemical GUS assay. These data demonstrate highly efficient Agrobacterium transformation of diverse alfalfa cultivars Xinjiang Daye, which enables routine production of transgenic alfalfa plants.
\end{abstract}

(Key words : Alfalfa, Agrobacterium, Molecular breeding, Transgenic plants)

\section{I . INTRODUCTION}

Alfalfa (Medicago sativa L.) is one of the most important forage legumes in the world (Kechang et al., 2009). It has the highest yield potential and feeding values and plays an important role in livestock industry (Hill et al., 1991). It is also a high quality forage crop and an important source of biological nitrogen fixation. Deak et al. (1986) first described that transgenic alfalfa plants were generated using Agrobacteriummediated gene transfer technique and there have been a few reports of stably transformed conifers using this technique (Ding et al., 2003; Chabaud, 2003; Rosellini et al., 2007). Plant transformation using Agrobacterium tumefaciens is advantageous due to single copy DNA insertion compared to particle bombardment transformation(Vain and Thole, 2009). Herbicide-resistant transgenic alfalfa is cultivated in more than 200,000 hectares in USA (James, 2011) and also there are several reports concerning the introduction of new traits to improve abiotic stresses such as salinity (Yan et al., 2012; Zhang et al., 2012), drought (Jiang et al., 2009) and heavy metal contamination (Zhang and Liu, 2011). To improve its genetic traits, it is necessary to optimize regeneration protocol in order to increase regeneration frequency and then to improve transformation efficiency of alfalfa for further study of molecular biological functions. Plant regeneration under in vitro conditions are affected by several different parameters such as selection of the genotype, concentration of phytohormones, bacterial strain, laboratory conditions, and the growth response of the explant to the regeneration medium. In addition, explant types could influence transformation efficiency (Bregitzer, 1992). The objective of this research was to develop a regeneration system for the selected cultivars and to optimize the conditions for transformation that could be effectively used for genetic improvement of alfalfa.

\footnotetext{
* Corresponding author: Ki-Won Lee, Grassland \& Forages Division, National Institute of Animal Science, Rural Development Administration, Cheonan, 330-801, Republic of Korea. Tel: +82-41-580-6754, Fax: +82-41-580-6779, E-mail: kiwon@korea.kr
} 


\section{П. MATERIALS AND METHODS}

\section{Explant source of alfalfa cultivars}

Seeds of five alfalfa cultivars (Xinjiang Daye, ABT405, Vernal, Wintergreen and Alfagraze) were collected from National Institute of Animal Science, Rural Development Administration (RDA), Republic of Korea. The seeds were first soaked in $70 \%(\mathrm{v} / \mathrm{v})$ ethanol for $1 \mathrm{~min}$ and then treated with $30 \%(\mathrm{w} / \mathrm{v})$ sodium hypochlorite $(\mathrm{NaOCl})$ for 30 min, followed by five time rinses with sterile water for surface sterilization. The sterilized seeds were germinated on hormone-free half-strength MS medium (Murashige and Skoog, 1962) containing $2 \%(\mathrm{w} / \mathrm{v})$ sucrose and $0.3 \%(\mathrm{w} / \mathrm{v})$ Gelrite (Table 1). Then cultured in a growth chamber at 24 $\pm 2^{\circ} \mathrm{C}$ in a $12 \mathrm{~h} \mathrm{light} / 12 \mathrm{~h}$ dark cycle. In vitro grown seedlings were used as the source of hypocotyl segments and cotyledonary explants.

\section{Transformation vector and bacterial strain}

Agrobacterium tumefaciens strain EHA105 harboring a binary vector pCAMBIA1301 was used for alfalfa transformation experiments. The binary vector consisted of the GUS gene under the control of the cauliflower mosaic virus (CaMV) 35S promoter, and the hygromycin phosphotransferase (HPT) under the control of the CaMV $35 \mathrm{~S}$ promoter promoter (Fig. 1).

The Agrobacterium tumefaciens culture was grown overnight in $50 \mathrm{~mL}$ YEP medium $(10 \mathrm{~g} / \mathrm{L}$ yeast extract, 10 $\mathrm{g} / \mathrm{L}$ bacto peptone, $5 \mathrm{~g} / \mathrm{L} \mathrm{NaCl}, \mathrm{pH} 7.0$ ) containing $50 \mathrm{mg} / \mathrm{L}$ kanamycin at $28^{\circ} \mathrm{C}$ on a rotary shaker at $200 \mathrm{rpm}$. To prepare Agrobacterium tumefaciens inoculum, an overnight culture of bacteria was centrifuged at $4,000 \mathrm{rpm}$ for $10 \mathrm{~min}$ at $4^{\circ} \mathrm{C}$ and the cells were resuspended in $100 \mathrm{~mL}$ of liquid AI medium (Table 1) to the optical density at $600 \mathrm{~nm}$ reaches $0.6-0.8$.

\section{Plant transformation and regeneration}

For transformation of selected cultivars, fully developed hypocotyl segments and cotyledonary explants from 7 days old seedlings were used as explants. Hypocotyls $1 \sim 3 \mathrm{~mm}$ explants were carefully excised from the seedlings without including any of the meristematic axillary buds and the cotyledonary were excised. The hypocotyl and cotyledonary segments were gently shaken in the bacterial suspension for about $30 \mathrm{~min}$ and blotted dry on a sterile filter paper. The hypocotyl and cotyledonary segments were transferred to the solid CCM medium (Table 1). Following 5 days of cocultivation, hypocotyl and cotyledonary segments transferred onto shoot induction SIM medium containing $250 \mathrm{mg} / \mathrm{L}$ carbenicillin and $15 \mathrm{mg} / \mathrm{L}$ hygromycin, and then, subcultured into a fresh SIM medium every 3 weeks. The green healthy shoots from the embryos were subjected to 2 3 more passages of selection by repeated excision of buds and their exposure to selective shoot elongation medium (SEM). Green healthy shoots were excised and transferred to shoot elongation SEM medium and developed shoots were transferred to root induction RM medium (Table 1). Rooted plants transferred to the soil $3 \sim 4$ weeks later. Callus induction and regeneration ratios of different genotypes and explants were calculated.

\section{Polymerase chain reaction (PCR) analysis of putative transgenics}

Total genomic DNA was isolated from young leaves of

\section{LB T35s hpt P35s P35s Int GUS Tnos RB}

\section{PCAMBIA1301}

Fig. 1. Schematic map of the T-DNA inserted in the pCAMBIA1301 binary vector. LB and RB diagram: left and right borders of the T-DNA; P35s: CaMV35s promoter; T35s and Tnos: CaMV35s terminator and nopline synthase gene terminator; hpt: hygromycin resistance gene; GUS: $\beta$-gluceronidase gene. 
Table 1. Composition of the media used for alfalfa transformation

\begin{tabular}{|c|c|c|}
\hline Step & $\begin{array}{l}\text { Medium } \\
\text { abbreviation }\end{array}$ & Composition \\
\hline $\begin{array}{l}\text { Germination } \\
\text { medium }\end{array}$ & GM & $1 / 2 \mathrm{MS}$, sucrose $20 \mathrm{~g} / \mathrm{L}$, Gelrite $3 \mathrm{~g} / \mathrm{L}$ \\
\hline $\begin{array}{l}\text { Agrobacterium } \\
\text { infection }\end{array}$ & AI & $\begin{array}{l}\text { 1/2 B5 macro, B5 vitamins, sucrose } 30 \mathrm{~g} / \mathrm{L}, \mathrm{L}-\mathrm{Proline} 0.5 \mathrm{~g} / \mathrm{L}, \mathrm{L} \text {-cystein } 10 \\
\mathrm{mg} / \mathrm{L}, \mathrm{AgNO}_{3} 5 \mathrm{mg} / \mathrm{L}, \mathrm{GA} 30.25 \mathrm{mg} / \mathrm{L}, \mathrm{BA} 2 \mathrm{mg} / \mathrm{L} \text {, acetosyringone } 100 \mu \mathrm{M} \text {, } \\
\mathrm{pH} 5.2\end{array}$ \\
\hline $\begin{array}{l}\text { Co-cultivation } \\
\text { medium }\end{array}$ & $\mathrm{CCM}$ & $\begin{array}{l}\text { B5 macro, B5 vitamins, sucrose } 30 \mathrm{~g} / \mathrm{L} \text {, L-Proline } 0.5 \mathrm{~g} / \mathrm{L}, \mathrm{GA} 30.25 \mathrm{mg} / \mathrm{L} \text {, BA } \\
2 \mathrm{mg} / \mathrm{L} \text {, acetosyringone } 100 \mu \mathrm{M} \text {, Agar } 6 \mathrm{~g} / \mathrm{L} \text {, pH } 5.2\end{array}$ \\
\hline $\begin{array}{l}\text { Shoot induction } \\
\text { medium }\end{array}$ & SIM & $\begin{array}{l}\text { B5 macro, B5 vitamins, sucrose } 30 \mathrm{~g} / \mathrm{L} \text {, L-Proline } 0.5 \mathrm{~g} / \mathrm{L}, 2,4-\mathrm{D} 1 \mathrm{mg} / \mathrm{L} \text {, } \\
\text { Kinetin } 0.1 \mathrm{mg} / \mathrm{L} \text {, cefotaxime } 250 \mathrm{mg} / \mathrm{L} \text {, Carbenicillin } 250 \mathrm{mg} / \mathrm{L} \text {, Hygromycin } 15 \\
\mathrm{mg} / \mathrm{L} \text {, Agar } 8 \mathrm{~g} / \mathrm{L} \text {, pH } 5.6\end{array}$ \\
\hline $\begin{array}{l}\text { Shoot elongation } \\
\text { medium }\end{array}$ & SEM & $\begin{array}{l}\text { B5 macro, B5 vitamins, sucrose } 30 \mathrm{~g} / \mathrm{L} \text {, L-Proline } 0.5 \mathrm{~g} / \mathrm{L}, \mathrm{GA} 30.5 \mathrm{mg} / \mathrm{L}, \mathrm{IAA} \\
0.1 \mathrm{mg} / \mathrm{L} \text {, Zeatin-riboside } 1 \mathrm{mg} / \mathrm{L} \text {, cefotaxime } 250 \mathrm{mg} / \mathrm{L} \text {, Carbenicillin } 250 \mathrm{mg} / \mathrm{L} \text {, } \\
\text { Hygromycin } 15 \mathrm{mg} / \mathrm{L} \text {, Agar } 8 \mathrm{~g} / \mathrm{L} \text {, pH } 5.6\end{array}$ \\
\hline Rooting medium & $\mathrm{RM}$ & $\begin{array}{l}1 / 2 \text { MS, sucrose } 20 \mathrm{~g} / \mathrm{L} \text {, IBA } 1 \mathrm{mg} / \mathrm{L} \text {, cefotaxime } 250 \mathrm{mg} / \mathrm{L} \text {, Hygromycin } 15 \\
\mathrm{mg} / \mathrm{L} \text {, Agar } 8 \mathrm{~g} / \mathrm{L} \text {, pH } 5.6\end{array}$ \\
\hline
\end{tabular}

hygromycin-resistant transgenic lines and a non-transformed control plant using the cetyl trimethylammonium bromide (CTAB) method (Murray and Thompson, 1980). PCR analysis was performed with the extracted genomic DNA to verify for the presence of transgenes in putative transformants using primer pairs that amplify each GUS and HPT transgenes. Optimized PCR conditions were performed according to Lee et al. $(2009 ; 2010)$. PCR products were separated by gel electrophoresis on $1.2 \%$ agarose gels, stained with ethidium bromide and visualized with a UV transilluminator.

\section{Histochemical staining of $\beta$-glucuronidase (GUS) activity}

Histochemical staining of the shoots was performed according to the method of Jefferson et al. (1987). Hygromycin-resistant plants were incubated in 5-bromo-4chloro-3-indolyl glucuronide (X-Gluc) at $37^{\circ} \mathrm{C}$ for overnight. Non-transgenic regenerated shoots were used as negative controls. After staining, the samples were washed with $70 \%$ ethanol for $2 \sim 3$ days to remove plant pigments. The ethanol bleach mixture was replaced three or four times then washed with double distilled $\mathrm{H}_{2} \mathrm{O}$.

\section{RESULTS AND DISCUSSION}

\section{Selection of an explant type for the regeneration of alfalfa cultivars}

In the preliminary experiments, the in vitro regeneration potential of selected cultivars was tested in two types of plant tissue such as hypocotyl and cotyledonary segments. Developing an efficient regeneration system of alfalfa by Agrobacterium-mediated transformation were evaluated by the percent of regenerated callus from hypocotyl and cotyledonary explants. Explants from hypocotyl resulted in high regeneration into calli compared to those from the cotyledonary explants (Table 2). Regeneration efficiency of cotyledons ranged from $0 \%$ (cv. Alfalgraze) to $9.3 \%(\mathrm{cv}$. Vernal) and hypocotyls from $2.2 \%$ (cv. Alfalgraze) to 18.5 $\%$ (cv. Xinjiang Daye). Also For all genotypes, callus inductions from hypocotyls were faster than cotyledons. Results are summarized in Table 2. It is well known that regeneration efficiency is an essential requirement for transformation efficiency.

\section{Efficiency of Agrobacterium-mediated transformation}

In this study, we evaluated transformation potential of the 
Table 2. Effect of alfalfa cultiver explant selection and regeneration

\begin{tabular}{lrrrrrrrrrrc}
\hline \multicolumn{1}{c}{ Alfalfa Cultivar } & \multicolumn{2}{c}{ ABT405 } & \multicolumn{2}{c}{ Alfalgraze } & \multicolumn{2}{c}{ Vernal } & \multicolumn{2}{c}{ Wintergreen } & \multicolumn{2}{c}{ Xinjiang Daye } \\
\hline \hline Explant type & A & B & A & B & A & B & A & B & A & B \\
No. of explants & 61 & 65 & 69 & 74 & 68 & 72 & 62 & 66 & 70 & 75 \\
No. of Calli & 48 & 54 & 32 & 45 & 43 & 54 & 27 & 36 & 55 & 65 \\
No. of regenerated plantlets & 2 & 7 & 0 & 1 & 4 & 2 & 0 & 1 & 4 & 12 \\
Regeneration frequency (\%) & 4.2 & 13.0 & 0 & 2.2 & 9.3 & 3.7 & 0 & 2.8 & 7.3 & 18.5 \\
\hline
\end{tabular}

1) $\mathrm{A}=$ cotyledons; $\mathrm{B}=$ hypocotyls.

five alfalfa cultivars and optimized conditions for obtaining transgenic alfalfa plants using Agrobacterium-mediated transformation into hypocotyl explants. Following the transformation of the hypocotyl explants, putative transformants were selected based on regeneration under hygromycincontaining B5 plates. In this study, carbenicillin was selected as an antibiotic used for suppressing the growth of Agrobacterium (Chabaud et al., 2007). Transformation rate was calculated as the proportion of healthy explants among all the tested genotypes, with an average transformation rate of $2.16 \%$. Xinjiang Daye varieties grew well and had 7.9 $\%$ transformation efficiency. Among the two genotypes Alfalgraze and Wintergreen showed $0 \%$ transformation rates.

To our knowledge, this is the report of the successful transformation of cultivars ABT405, Vernal and Xinjiang Daye. High transformation efficiencies were observed in alfalfa cultivars Xinjiang Daye. Genetic modification of an economically important alfalfa cultivar, Xinjiang Daye, gives us the possibilities to adapt them as a good candidate to improve genetic traits against current climatic changes, such as cold, heat, salinity and drought stresses.

\section{Analysis of transgenic alflalfa plants}

There were no morphological differences between control and putative transgenic plants. The genomic DNA from the leaves of 2-month-old putative transgenic plants were extracted and amplified with specific primers for the GUS and HPT genes. For PCR analysis, DNA was extracted from hygromycin resistant shoots expressing GUS signal. The amplified fragments by PCR were expected size $0.4 \mathrm{~kb}$ for GUS gene and $0.8 \mathrm{~kb}$ for HPT gene, while the control plants (wild type) did not show any bands in PCR amplification (Fig. 1). Histochemical GUS assay was performed by incubation of putatively transgenic alfalfa leaves with

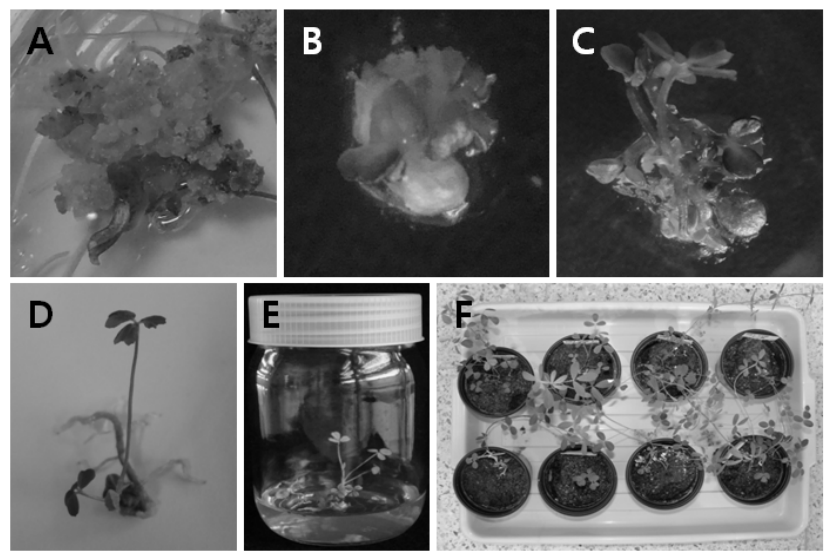

Fig. 2. Plant regeneration from hypocotyl segments in Alfalfa (Medicago sativa L.).

(A) Hypocotyl explants from 2 to 3 weeks-old seedlings on CIM; (B) Shoot initiation of hypocotyls at the end of 3 weeks on SIM; (C) Multiple shoot production and elongation on SEM; (D), (E) Isolated and elongated shoot with developing roots when cultured on RM; (E) Well rooted putative transgenic transferred to pots.

Table 3. Five alfalfa cultivars transformation and GUS expression

\begin{tabular}{lcccc}
\hline Cultivars & No. of explants & No. of GUS $^{+}$plants & No. of Hm ${ }^{\mathrm{R}}$ plants & $\begin{array}{c}\text { Transformation } \\
\text { efficiency (\%) }\end{array}$ \\
\hline \hline ABT405 & 135 & $14(10.3 \%)$ & 3 & 2.2 \\
Alfalgraze & 119 & $2(1.7 \%)$ & 0 & 0 \\
Vernal & 143 & $10(6.9 \%)$ & 1 & 0.7 \\
Wintergreen & 126 & $1(0.8 \%)$ & 0 & 0 \\
Xinjiang Daye & 140 & $29(20.7 \%)$ & 11 & 7.9 \\
\hline
\end{tabular}


X-gluc overnight and blue color formation occurred in the expression sites where X-gluc was catabolized by GUS gene product. Histochemical GUS staining analysis confirmed that the stable integration and expression of the GUS gene in the genome of the regenerated shoots of transgenic alfalfa plants and wild type (WT) plants did not show any blue staining (Fig. 3A).

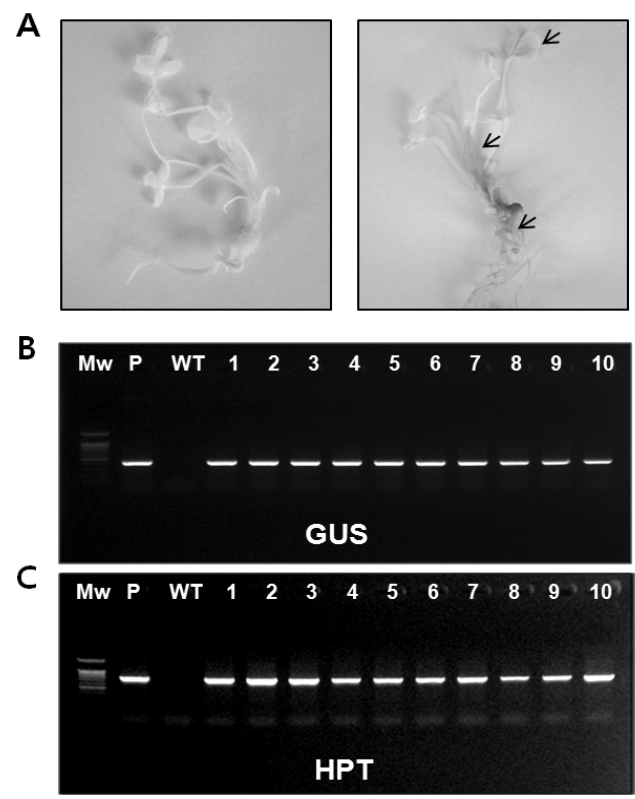

Fig. 3. PCR analysis of GUS and HPT genes in regenerated plants.

(A) A shoot from the regenerated plant showing GUS activity. Arrow indicates the position of the expected GUS activity. (B) Detection of GUS gene. (C) Detection of the HPT gene. Lane Mw, molecular markers, lane 1, plasmid pCAMBIA1301 from E. coli (positive control); lane 2, non-transformed wild type plant; 1-10, transgenic plants.

\section{CONCLUSION}

Agrobacterium tumefaciens-mediated transformation is generally used for genetic transformation for higher plants. Efficiency of Agrobacterium-mediated transformation in five alfalfa cultivars (Xinjiang Daye, ABT405, Vernal, Wintergreen and Alfagraze) was examined. As mentioned above, successful regeneration and genetic transformation systems for alfalfa are genotype dependent. The protocol designed could achieve a stable transformation frequency of Xinjiang Daye varieties having $7.9 \%$ efficiency for hypocotyl explants. Results on PCR analysis and histochemical GUS staining revealed the successful integration of transgene into alfalfa genome via Agrobacterium-mediated transformation. Based on our results, a case study is required to adapt the transformation techniques to a wide range of alfalfa cultivars. The low frequency of transformation may be attributed to many factors such as genotype, explant, bacterial strain, agro infection, laboratory conditions etc. Our procedure would be valuable in further research on genetic transformation with agronomically important genes involved in tolerance and/or avoidance against environmental stress such as drought, temperature, salinity and heavy metal contaminations.

\section{ACKNOWLEDGEMENTS}

This work was carried out with the support of "Cooperative Research Program for Agriculture Science \& Technology Development (Project No. PJ008599042014)" and 2014 year Postdoctoral Fellowship Program of National Institute of Animal Science, Rural Development Administration, Republic of Korea.

\section{REFERENCES}

Barik, D.P., Mohapatra, U. and Chand, P.K. 2005. Transgenic grasspea (Lathyrus sativus L.): Factors influencing Agrobacteriummediated transformation and regeneration. Plant Cell Reports. 24:523-531.

Bregitzer, P. 1992. Plant regeneration and callus type in barley: effect of genotype and culture medium. Crop Sci. 32(5):1108-1112.

Chabaud, M., Ratet, P., Araujo, S.S., Duque, A.S.R.L.A., Harrison, M. and Barker, D.G. 2007. Agrobacterium tumefaciens-mediated transformation and in vitro plant regeneration of $M$. truncatula. Medicago truncatula handbook.

Chabaud, M., de Carvalho-Niebel, F. and Barker, D.G. 2003. Efficient transformation of Medicago truncatula cv. Jemalong using the hypervirulent Agrobacterium tumefaciens strain AGL1. Plant Cell Reports. 22:46-51.

Deak, M., Kiss, G., Koncz, C. and Dudits, D. 1986. Transformation of Medicago by Agrobacterium-mediated gene transfer. Plant Cell Reports. 5:97-100.

Ding, Y.L., Aldao-Humble, G., Ludlow, E., Drayton, M., Lin, Y.H., Nagel, J., Dupal, M., Zhao, G.Q., Pallaghy, C., Kalla, R., Emmerling, M. and Spangenberg, G. 2003. Efficient plant regeneration and Agrobacterium-mediated transformation in Medicago and Trifolium species. Plant Science. 165:1419-1427.

Hill, K.K., Jarvis-Eagan, N., Halk, E.L., Krahn, K.J., Liao, L.W., 
Mathewson, R.S., Merlo, D.J., Nelson, S.E., Rashka, K.E. and Loesch-Fries, L. 1991. The development of virus-resistant alfalfa, Medicago sativa L.. Nature Biotechnology. 9:373-378.

James, C. 2011. Global status of commercialized biotech/GM crops: brief 43, International Service for the Acquisition of Agribiotech Applications ISAAA. pp. 1-16.

Jiang, Q., Zhang, J.Y., Guo, X., Monteros, M.J. and Wang, Z.Y. 2009. Physiological characterization of transgenic Alfalfa (Medicago sativa) plants for improved drought tolerance. Int. J. Plant Sci. 170:969-978.

Kechang, L., Ping, Z. and Cash, D. 2009. Biology and management of major alfalfa diseases and pests. In: Cash D, Yuegao $\mathrm{H}$, Kechang L, Suqin W, Ping Z, Rong G (eds) Alfalfa management guide for ningxia. China Agricultural Press. China. pp. 37-62.

Lee, K.W., Kim, K.Y., Lee, J.K., Park, H.S., Kim, K.H., Lee, B.H. and Lee, S.H. 2009. Factors influencing Agrobacterium-mediated transformation efficiency in perennial ryegrass. Journal of The Korean Society of Grassland and Forage Science. 29(3):165-170.

Lee, K.W., Choi, G.J., Kim, K.Y., Yoon, S.H., Ji, H.C., Park, H.S., Lim, Y.C. and Lee, S.H. 2010. Genotypic variation of Agrobacterium-mediated transformation of Italian ryegrass. Electronic Journal of Biotechnology. 13(3)1-10.

Rosellini, D., Capomaccio, S., Ferradini, N., Sardaro, M.L., Alessandro, N. and Veronesi, F. 2007. Non-antibiotic, efficient selection for alfalfa genetic engineering. Plant Cell Reports. 26:1035-1044.

Vain, P. and Thole, V. 2009. Gene insertion patterns and sites. In: Jones HD, Shewry PR(eds) Methods in molecular biology, transgenic, wheat, barley and oats. vol 478, Humana Press. New York. pp. 203-226.

Yan, L.P., Liu, C.L., Liang, H.M., Mao, X.H., Wang, F., Pang J.S., Shu, J. and Xia, Y. 2012. Physiological responses to salt stress of T2 alfalfa progenies carrying a transgene for betaine aldehyde dehydrogenase. Plant Cell Tissue Organ Culture. 108:191-199.

Zhang, H., Huang, Q. and SU, J. 2010. Development of Alfalfa (Medicago sativa L.) regeneration system and Agrobacteriummediated genetic transformation. Agricultural Sciences in China. $9(2): 170-178$.

Zhang, Y. and Liu, J. 2011. Transgenic alfalfa plants co-expressing glutathione S-transferase(GST) and human CYP2E1 show enhanced resistance to mixed contaminates of heavy metals and organic pollutants. J. Hazard Mat. 189:357-362.

Zhang, Y.M., Liu, Z.H., Wen, Z.Y., Zhang, H.M., Yang, F. and Guo, X.L. 2012. The vacuolar $\mathrm{Na}^{+}-\mathrm{H}^{+}$antiport gene TaNHX2 confers salt tolerance on transgenic alfalfa (Medicago sativa). Funct Plant Biol. Published online 18 July 2012.

(Received August 21, 2014 / Revised September 4, 2014 / Accepted September 15, 2014) 